\title{
Takeovers in China: The Case Against Uniformity in Corporate Governance
}

\author{
Guanghua Yu*
}

\begin{abstract}
Corporate governance has attracted enormous attention both in the area of law and in the area of financial economics. In comparative corporate governance studies, many people have devoted their energy to finding a best corporate governance model. I argue that a functional analysis does not support the view that there is a single best model in the world. I further use the transplantation of an English-style takeover law into China to explain that the importation of foreign law is not always based on careful analysis of whether the imported foreign law is the best in the world. Furthermore, I discuss the subsequent adjustment of the transplanted English takeover law to the takeover market in China to show that the transplantation of foreign law is subject to local political and economic conditions. If there is no best corporate governance model and the transplantation of foreign law into other countries with different social and political background does not achieve similar objectives, the search for a best corporate governance model is misguided.
\end{abstract}

\section{Introduction}

The problem of separation of corporate control and residual claims documented by Berle and Means has attracted considerable attention in the United States. ${ }^{1}$ The early economic explanation of the cause of the problem of separation of corporate control and residual claims is the emphasis on scale of economics and specialized knowledge of managerial experts. If the economic explanations were true, competitive economic forces would drive nations towards a single best model of corporate governance. Roe's pioneering works, however, find that similar matured economies have widely diversified corporate

* Associate Professor of Law, Faculty of Law, the University of Hong Kong; e-mail ghyu@hku.hk. Research support for this project was provided by the University of Hong Kong.

1 See A. Berle and G. Means, Jr., The Modern Corporation and Private Property (Harcourt: New York, 1968); G. Stigler and C. Friedland, The Literature of Economics: The Case of Berle and Means' (1983) $26 \mathrm{JL} \&$ Econ 237; H. Demsetz and K. Lehn, 'The Structure of Corporate Ownership: Causes and Consequences' (1985) $93 \mathrm{~J}$ Pol Econ 1155. 
governance regimes. ${ }^{2}$ Roe's research suggests that there are alternatives. Despite the differences in corporate governance regimes around the world, considerable research is still focused on the issue whether there is a best corporate governance model in the world. I argue from a functional approach in Section II that there might be no single best corporate governance model in the world. I examine in Section III the transplantation of an English-style takeover law in China and the adjustment of the transplanted takeover law under a different social and political background. The analysis reveals that similar legal provisions at the beginning may still lead to different adaptation and outcomes. I conclude in Section IV that even a functional analysis shows one corporate governance model does not fit all, not to mention the inclusion of larger social and political considerations.

\section{The Search for a Best Model}

The formation and growth of companies requires capital. Capital may be raised through equity financing or debt financing. Both methods of corporate finance result in frictions between users and suppliers of capital. Equity financing gives rise to the agency costs of equity financing while debt financing gives rise to the agency costs of debt financing. ${ }^{3}$ As the methods of financing corporate projects through either debt or equity are not mutually exclusive, ${ }^{4}$ most companies adopt both debt financing and equity financing. Differences, however, do exist. Companies in the United States and the United Kingdom rely far more heavily on the securities market than companies in Germany and France. For instance, while the United Kingdom has 36 listed firms per million citizens and the United States has 30, France and Germany have only eight and five respectively. ${ }^{5}$ Similarly, the ratio of total stock market capitalization to GDP contrasts sharply between Germany on the one hand and the United Kingdom and the United States on the other. In Germany, stock market capitalization was 17 per cent of the GDP during the middle of the 1990s as compared with 132 per cent of GDP in Great Britain. ${ }^{6}$ In the United States in 1995, the

2 M. Roe, 'A Political Theory of American Corporate Finance' (1991) 91 Colum L Rev 10; M. Roe, 'Some Differences in Corporate Structure in Germany, Japan, and the United States' (1993) 102 Yale LJ 1927.

$3 \mathrm{M}$. Jensen and W. Meckling, Theory of the Firm: Managerial Behavior, Agency Costs and Ownership Structure' (1976) $3 J$ Fin Econ 305.

4 F. Modigliani and M. Millars, The Costs of Capital, Corporate Finance, and the Theory of Investment' (1958, June) Am Econ Rev 48; but see Jensen and Meckling, above n. 3.

5 R. La Porta et al., 'Legal Determinants of External Finance' (1997) 52 J Fin 1131, 1137.

6 J. Gordon, 'Corporate Governance: Pathways to Corporate Convergence? Two Steps on the Road to Shareholder Capitalism in Germany' (1999) 5 Colum J Eur L $219,223$. 
stock capitalization of the New York Stock Exchange and NASDAQ was around 87 per cent of the total GDP. ${ }^{7}$

Different corporate finance methods create different sets of conflict of interest problems. The solutions to these different problems call for different corporate governance regimes. Corporate governance is defined as ways designed to make the management work for the best interests of the company and to assure a reasonable return to the suppliers of capital. In the United States, the supply of capital is predominantly from the securities market. In such an economy, the growth of companies under competitive conditions is mainly determined by scales of economics, ${ }^{8}$ shareholder diversification, ${ }^{9}$ reduction of transaction costs, ${ }^{10}$ and special knowledge of managerial experts. ${ }^{11}$ According to Demsetz and Lehn, share ownership concentration levels are inversely related to the aggregate size of the company. ${ }^{12}$ This relationship holds because as the value-maximizing size of the firm increases, the cost of acquiring a control block will also rise, deterring control accumulation. In addition, when the benefits from control transactions are smaller than the benefits resulting from share diversification, people will choose the latter. Berle and Means documented the phenomenon of widely dispersed shares in the United States. ${ }^{13}$ Within a regime where corporate finance is mainly from the securities market and shares are widely dispersed, the costs of equity financing would be higher if the corresponding corporate governance regime did not respond to agency problems well. As a matter of fact, the product market, the stock market, and the takeover market play important roles in the United States in solving the problem of conflict of interest between the management and the shareholders.

In Germany, initial public offerings historically have been rare, only 10 in all of $1994 .^{14}$ The stock markets are famously illiquid ${ }^{15}$ and volatile. ${ }^{16}$ Generally speaking, debt financing plays a much more significant role than equity financing in Germany. ${ }^{17}$ Debt financing creates the problem of conflict of interest between a borrowing company and the

7 See R. Karmel, 'Italian Stock Market Reform' (1998, 20 August) NYLJ at 3.

8 E. Fama and M. Jensen, 'Agency Problems and Residual Claims' (1983) $26 \mathrm{JL}$ and Econ 327.

$9 \mathrm{~K}$. Arrow, The Role of Securities in the Optimal Allocation of Risk Bearing' (1964) 31 Rev Econ Stud 97.

10 R. Coase, The Nature of the Firm' (1937) 4 Economica 386.

11 See Fama and Jensen, above n. 8.

12 Demsetz and Lehn, above n. 1 at 1158.

13 Above n. 1.

14 See Gordon, above n. 6 at 220.

15 The top six firms accounted for almost 50 per cent of the volume in public markets: ibid.

16 See S. Prigge, 'A Survey of German Corporate Governance' in K. Hopt et al., Comparative Corporate Governance-The State of the Art and Emerging Research (Clarendon Press: Oxford, 1998) 943, 998-90.

17 D. Neuberger and M. Neumann, 'Banking and Antitrust: Limiting Industrial Ownership by Banks' (1991) J Institutional and Theoretical Econ 147, 188-99. 
creditor. The corporate governance regime in Germany was very responsive to the agency costs of debt financing. German banks' historical and significant roles in debt financing, without political and legal constraints, make it desirable for them to have the option of holding shares in the debtor companies. ${ }^{18}$

In debt financing, creditors normally can intervene in the debtors' business only after debtors default. As bankruptcy generally diminishes claims of general creditors, creditors prefer early exit if they do not have sufficient control of the debtor. If a creditor is also a major shareholder, it may deter wealth transfer transactions. Ex ante, the creditor-shareholder may prevent wealth transfer transactions being adopted by the management of the borrower. Such intervention is normally done by the creditor-shareholder's representative on the supervisory board. The supervisory board can always ask the management board for reports. The supervisory board may also ask the management board to obtain its approval before important transactions, such as credits above a certain amount. ${ }^{19}$

Ex post, the creditor-shareholder may penalize managers through the supervisory board. Significant shareholding in the debtorcompany makes voice more important than exit; otherwise the creditor-shareholder will suffer both on equity investment and on credit investment. Thus, it is not surprising to see that German banks often take over the reorganization of companies in distress. ${ }^{20}$ Empirical studies show that there is a significant involuntary 'fluctuation' of management board members not only in cases of serious problems within the company but also in less serious cases in which the supervisory board was displeased with the performance of individual managers or with the management board as a whole. ${ }^{21}$ Hence, creditor-shareholders' active participation in corporate governance in Germany reduces both the agency costs of debt financing and the agency costs of equity financing.

The search for a best corporate governance model has been in existence since the beginning of the 1990s. Porter argued that the Anglo-American pattern of dispersed ownership was clearly inferior to the bank-centred capital markets of Germany and Japan, because the latter enabled corporate executives to manage for the long run, while United States managers were allegedly forced to maximize short-term earnings. ${ }^{22}$ Grundfest argued that the US regulatory regime systematically subordinated investors' desire to resolve agency

18 See T. Baums, 'Corporate Governance in Germany: The Role of the Banks' (1992) 40 Am J Comp L 503, 508.

$19 \mathrm{Ibid}$. at 510.

20 Ibid. at 512.

21 Ibid. at 515-16.

22 See M. Porter, 'Capital Disadvantage: America's Failing Capital Investment System' (1992, Sept-Oct) Harv Bus Rev 65. 
problems to managers' desire to be protected from capital market discipline. ${ }^{23}$ He states:

As a consequence of the harmony of interests created by joint equity and debt holding position, Japanese firms have to compensate lenders less to induce them to bear the risks associated with potential bondholder-stockholder conflict. Thus, all else being equal, Japanese capital structures reduce agency costs and allow investors to monitor management more effectively than in the United States. In particular, the amelioration of agency problems allows Japanese firms to invest more in research and development and to maintain more liquid and flexible asset structures than their comparably leveraged American counterparts.

Similar criticisms of the American corporate governance regime can be found in the political theories. Political theories explain the dispersed share ownership in large American companies as the product of political forces and historical contingencies as well as economic efficiency. ${ }^{24}$

Doubts were soon raised concerning whether the corporate governance regime in the United States is inferior to its counterparts in Japan and Germany. Macey and Miller argue that powerful banks in corporate governance carry with them an entirely new set of conflicts between the risk-averse claimants who make loans and the residual claimants who invest risk capital, preventing the equity claimants from undertaking socially optimal risks. ${ }^{25}$ The argument of Macey and Miller is not entirely satisfactory, however. The conclusion that powerful banks as fixed claimants care far less about maximizing their firms' potential upside performance than about minimizing potential downside performance ignores a major fact that German universal banks sometimes do hold substantial shares in the borrowing companies. For instance, in 1986 the Deutsche Bank held 41.8 per cent of the shares in Daimler-Benz, 30.82 per cent of the shares in Bayer and 17.64 per cent of the shares in Siemens. ${ }^{26}$ Presumably, the Deutsche Bank would also be able to share a high proportion of benefits from the optimal risk-taking activities in these borrowing companies.

Neoclassical economists have long argued that efficiency considerations ultimately prevail and determine corporate structure. Stigler and Friedland criticize the main theme of Berle and Means on the ground that empirical evidence available at the time when Berle and

23 J. Grundfest, 'Subordination of American Capital' (1990) 27 J Fin Econ 89.

24 See Roe, 'A Political Theory' above n. 2; J. Pound, The Rise of the Political Model of Corporate Governance and Corporate Control' (1993) 68 NYL Rev 103; also see Grundfest, above n. 23.

25 J. Macey and G. Miller, 'Corporate Governance and Commercial Banking: A Comparative Examination of Germany, Japan, and the United States' (1995) 48 Stan L Rev 73, 77-81.

26 See Roe (1993), above n. 2 at 1937. 
Means wrote their book was not able to establish any effect of different type of control on profits. ${ }^{27}$ Demsetz views the ownership structure of the company as an endogenous outcome of a maximizing process. ${ }^{28}$ While agency costs may be higher in companies with dispersed shareholding structure, their higher costs may be more than offset by the reduction in risk-associated capital cost, benefits from economic scales and specialized knowledge of managers. ${ }^{29}$

More recently, the focus of studies is on the relationship between a jurisdiction's ability to finance economic development and growth and its legal system. ${ }^{30}$ As previously discussed, the United States and the United Kingdom have strong stock markets while Germany and France have relatively weak stock markets. Financial economists in this school argue that only those legal systems that provide significant protection for minority shareholders can develop active equity markets. ${ }^{31}$ Coffee raises the point that, if this explanation from financial economists is accepted, it amounts to a rejection of the political theory of American corporate finance offered by Roe and others. ${ }^{32}$ This is so because dispersed share ownership may be the product not of political constraints on financial institutions; instead, it is strong legal protection, which encourages investors to become minority owners. ${ }^{33}$ This point is not new. Demsetz once said that in a world in which selfinterest plays a significant role in economic behaviour, it is foolish to believe that owners of valuable resources systematically relinquish control to managers who are not guided to serve the interests of owners. $^{34}$

Regardless of whether the dispersed ownership structure in the United States is a function of legal restrictions on financial institutions, the explanation that concentrated ownership becomes the consequence of weak legal protections for public or minority investors ${ }^{35}$ is not entirely satisfactory. It is true that the premium for control blocks in Italy is much higher than in the United States, ${ }^{36}$ but it is still difficult to come to the conclusion that the concentrated ownership structure is worse than the dispersed ownership structure. Shareholders with concentrated ownership have both the incentives and

27 Stigler and Friedland, above n. 1.

$28 \mathrm{H}$. Demsetz, 'The Structure of the Ownership and the Theory of the Firm' (1983) $26 J L$ \& Econ 375.

$29 \mathrm{Ibid}$. at 386.

30 See La Porta et al., above n. 5; see also A. Demirguc-Kunt and V. Maksimovic, 'Law, Finance and Firm Growth' (1998) 53 J Fin 2107, 2134.

31 See La Porta et al., above n. 5; see also A. Shleifer and R. Vishny, 'A Survey of Corporate Governance' (1997) 52 J Fin 737.

$32 \mathrm{~J}$. Coffee, Jr., The Future as History: the Prospects for Global Convergence in Corporate Governance and Its Implications' (1999) 93 NW UL Rev 641, 644.

33 Ibid.

34 See Demsetz, above n. 28 at 390.

35 See La Porta et al., above n. 5 at 1132.

36 See L. Zingales, The Value of the Voting Right: A Study of the Milan Stock Exchange Experience' (1994) 7 Rev Fin Stud 125. 
ability to monitor the management team. The higher share premium for control is a reward of their monitoring activities. It is very difficult to argue that a system linking monitoring efforts with reward is defective. Although the share premium for control is low in the United States, compensation to managers is much higher in the United States than in Germany and Japan. ${ }^{37}$ For instance, in the year before the merger the Chrysler Chief Executive Officer (CEO) received cash compensation of US\$ 6 million and stock options worth US\$ 5 million while the Daimler CEO received approximately one-eighth of that amount. ${ }^{38}$ A plausible explanation is that minority shareholders in countries with dispersed ownership have to provide the managers and CEOs with greater remuneration to motivate the managers to maximize the shareholders' wealth. These differences are, however, not able to suggest which system is better from a contractual perspective. The ability to survive in a large number of countries indicates that concentrated ownership is also consistent with efficiency given the relevant constraints in these economies. Concentrated ownership, however, may also occur in a country with good legal protection to minority shareholders. For instance, entrepreneurs prefer to have control when venture capitalists exit from successful firms. ${ }^{39}$ Leveraged buyouts (LBOs) provide another example that just as dispersed ownership in the United States is consistent with efficiency, ${ }^{40}$ so is concentrated ownership in the United States. Shleifer and Vishny point out that LBOs are efficient organizations as large investors reduce agency problems. ${ }^{41}$

So far, there is no clear evidence to show whether the corporate governance system in the United States is better or worse than the corporate governance system in Japan or Germany. Claims that one corporate governance system is better than the other are largely influenced by the prosperity of the economy in that country compared with the economy in another country. For instance, when the Japanese economy was very successful until at least the beginning of the 1990s, many people expressed their preference for the Japanese corporate governance system. ${ }^{42}$ The economic performance in the United States in the 1990s has, however, changed the tide in the corporate

37 S. Kaplan, 'Top Executives, Turnover, and Firm Performance in Germany' (1994) $10 \mathrm{JL}$ Econ and Org 142-59; S. Kaplan, Top Executive Rewards and Firm Performance: A Comparison of Japan and the United States' (1994) 102 J Pol Econ $510-46$.

38 Gordon, above n. 6 at 236.

39 D. Smith, The Venture Capital Company: A Contractual Rebuttal to the Political Theory of American Corporate Finance?' (1979) 65 Tenn L Rev 79.

40 See Demsetz, above n. 28 at 386.

41 See Shleifer and Vishny, above n. 31 at 776.

$42 \mathrm{M}$. Aoki, 'Towards an Economic Model of the Japanese Firm' (1990) $28 \mathrm{~J}$ Econ Literature 1; Grundfest, above n. 23; J. Charkham, Keeping Good Company: A Study of Corporate Governance in Five Countries (Clarendon Press: Oxford, 1994); M. Porter, above n. 22. 
governance literature. Soon people voiced their views that the corporate governance system in the United States may be actually better than that in Japan and Germany. ${ }^{43}$

Since it is difficult to use the connection between corporate governance and economic performance to establish the claim that a particular corporate governance system is superior to another, we are still further away from discovering the best corporate governance model. The major difficulty with connecting corporate governance systems with economic performance is that the approach fails to measure the substitution effects and the effects of complementarities of the different diversified subsystems in different corporate governance systems.

\section{Transplantation and Adjustment of an English-Style Takeover Law in China}

In Part $\mathrm{i}$ of this section, I try to explain that the transplantation of a foreign law may be quite accidental rather than based on careful cost and benefit analysis of the best law among available options. The adoption of an English-style takeover law at the beginning of the 1990s in China can be explained by chaos theory. I analyse in Part ii with empirical evidence the theory of path-dependence and conclude that the adaptation of the transplanted law to a different country with differing social and political background is path-dependent. The case of the transplanted English-style takeover law in China provides good evidence that adaptation of the transplanted foreign law in a different country is subject to local social and political forces. This also shows that there are diversified corporate governance subsystems because of local adaptation and innovation.

\section{i. Chaos Theory and the Importation of Takeover Law}

China's company law and the stock market were mainly designed to improve the performance of the inefficient state-owned enterprises (SOEs). ${ }^{44}$ As a part of the company law, the law of takeover had similar purposes for SOEs. This Part will discuss the poor performance of SOEs and banks until the beginning of the 1990s. The inefficiency of the SOEs called for a major change of corporate finance from bank loans to issuing shares to the public through the stock exchanges both in China and outside China, particularly in Hong Kong.

43 Macey and Miller, above n. 25; C. Milhaupt, The Market for Innovation in the United States and Japan: Venture Capital and the Comparative Corporate Governance Debate' (1997) 91 Nw UL Rev 865; La Porta et al., above n. 5; Demirguc-Kunt and Maksimovic, above n. 30.

44 R. Art and Minkang Gu, 'China Incorporated: the First Corporation Law of the People's Republic of China' (1995) 20 Yale J Int'l L 273, 274-5. 
Although reform of SOEs started in 1978, performance of SOEs and banks remained poor in the 1980s and at the beginning of the 1990s. In 1987, losses incurred by state-owned, economically independent industrial enterprises amounted to 6.1 billion yuan..$^{45}$ Losses increased to 34.8 billion yuan in 1990 and to 45.2 billion yuan in $1993 .{ }^{46}$ During the first four months of 1994, 50.1 per cent of these enterprises were running at a loss. ${ }^{47}$ Although things improved slightly in the latter half of that year, 34.4 per cent of these SOEs were still running at a loss at the end of $1994 .{ }^{48}$ Overstocking of products, chain defaulting of debts, and poor management of funds have taken an increasingly heavier toll on the economic performance of enterprises. For instance, stockpiled products were valued at 412.4 billion yuan at the end of $1994 .{ }^{49}$ Most of these losses resulted from medium- to large-sized SOEs.

Despite the reform of the financial sector, performance of the banks remained poor at the beginning of the 1990s. Overdue payments and non-performing loans were high. While official reports indicate that overdue payments and non-performing loans accounted for 15 per cent of all credit offered by banks in 1992, unofficial estimates show that overdue payments and non-performing loans were close to 40 per cent of all outstanding loans. ${ }^{50}$ The continuation of the dominant means of financing SOEs by loans from state banks would generate political risks of bank insolvency when banks were unable to tighten the soft budget constraints of various loan users. ${ }^{51}$

Soft budget constraints and the legal prohibition against banks from owning shares in non-financial companies require the use of alternative means of financing corporate activities. The stock market was a natural selection. It is argued that if share prices reflect enterprise profitability, capital markets will channel investment funds to the most efficient enterprises as investors seek to maximize their returns. ${ }^{52}$ It is further argued that capital markets create a market for corporate control. The reformers believe that market mechanisms are

45 Project Group of the Chinese Academy of Social Sciences, 'Several Problems Related to the Establishment of a Modern Enterprise System' (1996) 17(4) Social Sciences in China 19, 20.

46 Ibid.

47 Ibid.

48 lbid.

49 Ibid.

50 Zhou Zhengqing, 'Explanations Concerning the Commercial Banking Law of the PRC', a speech delivered at the Thirteenth Session of the Eighth Standing Committee of the National People's Congress; interview with Mr Cai, a middlelevel manager with the Bank of China in Hangzhou on 25 May 1993.

51 See J. Kornai, Economics of Shortage (North-Holland Publishing Co.: Amsterdam, 1980) for a discussion about soft budget constraints; for a discussion on the difficulty of enforcing the Bankruptcy Law in China in the 1990s, see Guanghua $\mathrm{Yu}$, The Relevance of Comparative Corporate Governance Studies for China' (1997) 8(1) Australian J Corp L 49, 79-80.

52 See Xu Jingan, The State-share System: A New Avenue for China's Economic Reform' (1987) $11 \mathrm{~J}$ Comp Econ 509, 514. 
more efficient at rationalizing productive assets than the powers given to banks. ${ }^{53}$

Under the support of reformers, two stock exchanges respectively opened in Shanghai in 1990 and in Shenzhen in $1991 .{ }^{54}$ Raising capital domestically was not the only objective. The government was also active in utilizing foreign capital, particularly through Hong Kong. The demand of raising foreign capital mainly through Hong Kong at the beginning of the 1990s gave the regulatory experts in Hong Kong the opportunity to persuade the relevant authorities in China to adopt certain necessary laws and regulations similar to those used in Hong Kong.

The regulations passed in that period provide some evidence that China was keen to use Hong Kong as a base for the purpose of raising foreign capital. Before the Company Law was enacted in 1993, the State Economic Restructuring Commission issued the Opinions on the Standardization of Joint Stock Companies (Standardization Opinions) ${ }^{55}$ in 1992 to facilitate the conversion of state-owned enterprises to joint stock companies. Soon after the issuance of the Standardization Opinions, the State Economic Restructuring Commission issued the Supplementary Measures Concerning the Implementation of the Opinions on the Standardization of Joint Stock Companies by Companies Seeking a Listing in Hong Kong (Supplementary Measures). ${ }^{56}$ These Supplementary Measures were designed to adapt the listing in Hong Kong by companies incorporated in China.

As the Standardization Opinions and the Supplementary Measures do not contain detailed provisions for the protection of minority shareholders, the concern about the extent of the protection of minority shareholders in Hong Kong has to be addressed. For this purpose, the Mainland and Hong Kong Joint Working Committee on Securities Affairs was established with the approval of the State Council. The Essential Clauses of the Articles of Association of Companies Seeking a Listing in Hong Kong proposed by this Committee were endorsed by the State Economic Restructuring Commission (Articles of Association). ${ }^{57}$

In the Articles of Association, typical English company law provisions, among other things, on the duty of directors ${ }^{58}$ and remedies of

53 Ibid.

54 Andrew Xuefeng Qian, 'Riding Two Horses: Corporatizing Enterprises and the Emerging Securities Regulatory Regime in China' (1993) 12 UCLA Pac Basin LJ $62,63$.

55 The Standardization Opinions appeared in the Collection of the Laws of the PRC (Jilin People's Press: Jilin, 1992) 650.

56 The Supplementary Measures were issued by the Commission on 24 May 1993 and are available online at <http://www.chinainfobank.com > .

57 These mandatory model Articles of Association were issued by the State Economic Restructuring Commission on 30 June 1993 and appear at <http://www.chinainfobank.com >.

58 Articles of Association, Art. 4.4. 
a company in case of breach of duties ${ }^{59}$ can be found. The Standardization Opinions were replaced by the Company Law enacted in 1993 and the Articles of Association were replaced by the Prerequisite Clauses of the Articles of Association of Companies Seeking a Listing Outside the PRC (Prerequisite Clauses) in 1994. ${ }^{60}$ In 1993, the State Council also promulgated the Tentative Regulation on the Administration of the Issuing and Trading of Shares (ITS). ${ }^{61}$ These laws and regulations provided the legal infrastructure for the issuing and trading of shares both on the stock exchanges in China and the stock exchange in Hong Kong by companies incorporated in China.

In the ITS, provisions on takeovers are very similar to the Hong Kong Code on Takeovers and Mergers, ${ }^{62}$ which was itself based on the London City Code on Takeovers and Mergers. ${ }^{63}$

Chaos theory shows that some phenomena are extremely sensitive to historical events. ${ }^{64}$ According to chaos theory, accurate predictions about where a system is heading are hard to make. The winding road described by Roe is a good example. ${ }^{65}$ Today's winding road depends upon early fur traders' choice to avoid a wolves' den close to a potentially straight road. Had the fur traders been better hunters of wolves, they might have chosen a straight road. The common law system in many different parts of the world is another example which shows that historical events matter. The colonization of countries or regions including Canada, Australia, New Zealand, and Hong Kong led to the transplantation of the English-style common law system in these countries or regions. Similarly, China's utilization of capital overseas, discussed previously, played a critical role in the transplantation of the English-style takeover law. ${ }^{66}$ The People's Republic of China maintained a rigid socialist economic planning system from 1949 to 1978. It was the Economic Reform Programme initiated at the end of the 1970s which significantly changed the way of financing corporate activities. An important part of the policy change was the utilization of capital through the stock market to be established in China and existing stock markets outside China, particularly in Hong Kong. The

59 Articles of Association, Art. 4.8.

60 The Prerequisite Clauses were issued by the Securities Office of the State Council and the State Economic Restructuring Commission on 19 September 1994. An English translation appears at China Law \& Practice (Asia Law and Practice Publishing Ltd: Hong Kong, May 1995) 19.

61 An English translation of this Regulation appears at China Law \& Practice (Asia Law and Practice Publishing Ltd: Hong Kong, August 1993) 23.

62 The Code is available online at <http://www.hksfc.org.hk > .

63 London City Code on Takeovers and Mergers, 7th edn (2002), available online at <http://www.thetakeoverpanel.org.uk >.

64 See J. Gleick, Chaos: Making a New Science (Heinemann: London, 1988) 8; also see M. Roe, Commentary: 'Chaos and Evolution in Law and Economics' (1996) 109 Harv L Rev 641.

65 Roe, above n. 65 at 643.

66 See above nn. 55 to 64 and the accompanying text. 
inducement of capital in Hong Kong gave great leverage to the regulatory authorities in Hong Kong to persuade the Chinese regulatory authorities to adopt a takeover law which is familiar to them and is from the United Kingdom. The next part will discuss the adaptation of the transplanted English-style takeover law in China.

\section{ii. The Law and Adjustment}

As discussed previously, China's early takeover transactions were regulated by the ITS. ${ }^{67}$ While there are only seven articles on takeovers in the ITS, the key provision is based on the London City Code. ${ }^{68}$ According to this provision, within 45 working days after any legal person's (other than a promoter's) direct or indirect holding of outstanding common shares in a listed company reaches 30 per cent of such company's total outstanding common shares, such legal person shall make an offer of takeover to all the shareholders of the target company, offering to purchase their shares through cash payment. ${ }^{69}$ If a takeover is made, the higher of the following two prices should be adopted as the offer price: (1) the highest price paid by the offeror for the purchase of such shares during the 12 months preceding the issuance of the takeover offer; or (2) the average market price of such shares during the 30 working days preceding the issuance of the takeover offer.$^{70}$ I will call this provision the mandatory purchase provision and further discuss it later.

A few other provisions are related to fair treatment of minority shareholders and are much easier to justify. For instance, all the conditions contained in a takeover offer shall apply to all the holders of the same kind of shares. ${ }^{71}$ If the total number of shares that the maker of a takeover offer prepares to buy is less than the total number of shares for which the offer is accepted, the offeror shall purchase shares from the offeree shareholders on a pro rata basis. ${ }^{72}$ In the event of a change in any of the main conditions of offer after a takeover offer has been issued, the offeror shall promptly notify all offerees. ${ }^{73}$ Such notice may be made in the form of a press conference or newspaper announcement or by another means of dissemination. During the term of a takeover offer and for a period of 30 working days

67 ITS, above n. 62 and the accompanying text.

68 London City Code, above n. 64 at Section 9.1.

69 ITS, Art. 48.

70 bid. The current price provision in the Procedures on the Administration of the Takeover of Listed Companies issued by the China Securities Regulatory Commission on 28 September 2002 follows the higher of the following two: (1) the highest price the acquirer paid during the six months prior to the date of public announcement; and (2) 90 per cent of the arithmetic mean of the daily weighted average prices of the target company's listed shares of that class during the 30 days prior to the date of public announcement. Below n. 77.

71 ITS, Art. 50.

72 Ibid., Art. 51(3).

73 Ibid., Art. 52(1). 
thereafter, the offeror may not purchase the shares in question on any conditions other than those set forth in the offer. ${ }^{74}$

Still other provisions are related to disclosure and the facilitation of potential competing takeover offers. If a legal person holds, pursuant to the disclosure provision, directly or indirectly, more than 5 per cent of the common shares of another listed company, a public announcement shall be made and a written report disclosing the fact shall be sent to the listed target company, the relevant stock exchange and the China Securities Regulatory Commission (CSRC) within three working days from the date of acquisition. ${ }^{75}$ In addition, any change of increase or decrease of the above acquired shares of such a legal person reaching 2 per cent will again trigger the reporting duty. ${ }^{76}$ Such a legal person shall not directly or indirectly buy or sell shares of the target company two working days from the date when it makes the announcement and submits the report and before the submission of the report. ${ }^{77}$ According to another provision for the purpose of facilitating takeover offers, the takeover offer period, calculated from the date of issuing the offer, shall not be less than 30 working days. ${ }^{78}$ Offerors shall not withdraw their takeover offer during the offer period. ${ }^{79}$ Furthermore, the offeree shareholders have the right to withdraw their acceptance during the offer period..$^{80}$ As will be discussed later, the political goal of maintaining control over the large SOEs makes the disclosure provision and the provision for facilitating competing takeover offers irrelevant in the 1990s.

The mandatory purchase provision was adopted in the United Kingdom in $1968^{81}$ and later widely spread to many other countries or regions such as Australia, ${ }^{82}$ Germany, Portugal, Italy, and Switzerland. ${ }^{83}$ The takeover law in the United States does not have such a provision. The rationale behind the provision is the equality of treatment of minority shareholders. If an acquiring company pays a premium to the majority, block or some shareholder(s) in a target when purchasing their shares, the acquiring company shall also be required to extend the same premium to the minority shareholders in the target company. An introductory provision in the London City Code reflects that policy concern. The provision stipulates that the Code is designed

74 Ibid., Art. 52(2).

75 Ibid., Art. 47(1).

$76 \mathrm{Ibid}$., Art. 47(2). The current position is 5 per cent under the Securities Act 1998 instead of 2 per cent.

77 Ibid., Art. 47(3).

78 Ibid., Art. 49(2).

79 Ibid.

80 Ibid., Art. 52(3).

81 P. Lee, Takeovers-The United Kingdom Experience' in J. Farrar (ed.), Takeovers: Institutional Investors and the Modernization of Corporate Law (Oxford University Press: Oxford, 1993) 192.

82 R. Austin, above n. 82 at 144.

83 P. Davies and K. Hopt, 'Control Transactions' in Reinier Kraakman et al. (eds.), The Anatomy of Corporate Law (Oxford University Press: Oxford, 2004) 179-80. 
principally to ensure fair and equal treatment of all shareholders in relation to takeovers. ${ }^{84}$ This rationale, however, is based on an unrealistic assumption that whatever the law, the number of takeovers will not be reduced. The provision takes the ex post view that the gains, once a takeover takes place, from the takeover should be shared equally by all the shareholders in the target.

Before proceeding to an evaluation of the mandatory purchase provision, it is necessary to discuss the motivations of acquiring companies in taking over target companies. The transfer of a controlling interest in a given company will take place in two types of situations. First, an acquiring company may believe that the target company in question can be managed in a more efficient manner and will thus generate more profit as the incumbent managers are indulging in excessive perquisites or are not working hard. ${ }^{85}$ Second, the acquiring company may be able to employ synergistic practices to realize economies of scale or scope after the takeover to increase the profits. ${ }^{86}$ In both of the above cases, the transfer of control will be efficient at a price between the ceiling price of the present value of the future income stream generated by the acquiring company and the floor price of the present value of the future income stream of the firm as it is currently being operated by the target management. While abusing minority shareholders may occur in some takeovers, which can be safeguarded by the general corporate law on the protection of minority shareholders and on penalties being imposed on looters,${ }^{87}$ empirical evidence to a large extent supports the theories of disciplining inefficient managers and of synergy effects. ${ }^{88}$

The mandatory purchase provision can be evaluated by the autonomy value and the welfare value. ${ }^{89}$ Neither criterion can justify this premium sharing provision. On a Nozickian rights-based approach, a distinction is made between threats and offers. ${ }^{90}$ Threats reduce the possibilities open to the recipient of an offer whereas offers expand them. From that perspective, takeovers would seem properly to be viewed as offer rather than as threat. The possibility of having a new management team indicates that takeovers increase target shareholders' possibilities relative to their position prior to their interaction

84 London City Code, above n. 64 at Section 1(a).

85 M. Jensen, 'Takeovers: Their Causes and Consequences' (1988) $2 \mathrm{~J}$ Econ Perspectives 21; R. Morck et al., 'Alternative Mechanisms for Corporate Control' (1989) 79 American Econ Rev 545.

86 See Roberta Romano, 'A Guide to Takeovers: Theory, Evidence, and Regulation' (1992) Yale J on Reg 119.

87 See Inshuranshares Corp. v Northern Fiscal Corp. 35 F Supp 22 (ED Pa, 1940).

88 G. Jarrell et al., The Market for Corporate Control: The Empirical Evidence Since 1982' (1988) 2 J Econ Perspectives 49; M. Jensen and R. Ruback, The Market for Corporate Control: The Scientific Evidence' (1983) $11 \mathrm{~J}$ Fin Econ 5.

89 See M. Eisenberg, The Theory of Contracts' in P. Benson (ed.), The Theory of Contract Law (Cambridge University Press: Cambridge, 2001) 206.

90 R. Nozick, 'Coercion' in Sidney Morgenbesser et al. (eds.), Philosophy, Science, and Method (St Martin's Press: New York, 1969) 447-53. 
with the acquirer. Even the threat of takeovers disciplines managers in a potential target company.

Despite the conclusion that takeover transactions enlarge shareholders' contractual possibilities and despite the overwhelming empirical evidence that shareholders of target companies receive abnormal returns resulting from takeover transactions, ${ }^{91}$ an enormous body of academic writing has focused on the problem of coercion in takeovers, particularly in partial bids. ${ }^{92}$ Coffee notes that demonstrated examples of coercion remain as rare as confirmed sightings of the Loch Ness monster. ${ }^{93}$ The ex ante Nozickian rights-based approach provides hardly any justification for the mandatory purchase provision. If takeovers enlarge the opportunities of the target shareholders as they are considered as offers rather than threats, mandatory purchase provisions cannot be justified. Even from the perspective of the remaining target shareholders, mandatory purchase provisions may reduce their contractual opportunities as the heavy burden of the provision on the acquirer could result in few takeovers ex ante. Ex post, mandatory purchase provisions may be viewed as offers to particular offeree shareholders in the target as they can choose either to sell their shares to the acquirer with the premium or to remain in the target and expect the improvement of the target by the acquirer. Mandatory purchase provisions, however, are certainly threats to the acquiring company and the shareholders in the acquiring company. If takeovers do not create third party effects of coercion on the remaining shareholders in the target, it is not clear why the contractual freedom between the acquirer and part of the shareholders in the target should be restrained.

The autonomy value provides little support for such a provision. Welfare value would also object to the mandatory purchase provision. Mandatory purchase provisions increase the cost of acquiring the control of target companies. The harmful effects of the mandatory purchase provision are obvious. In the first place, mandatory purchase provisions reduce the number of offers by making targets more expensive to acquire. According to the economic law of demand, the higher the price, the lower the demand from purchasers. Lower demand in the context of takeovers means fewer takeovers, hence, possibly a smaller pie for society. Secondly, the philosophy of sharing the gains from takeover transactions contained in the mandatory purchase provision reduces the return of investment on the part of the acquirer. The inability of acquirers to appropriate the full value of their investment will lead them to undertake too few takeovers. This is

91 See Jarrell et al., above n. 89; Jensen and Ruback, above n. 89.

92 L. Lowenstein, 'Pruning Deadwood in Hostile Takeovers: A Proposal for Legislation' (1983) 83 Colum L Rev 249; M. Bradley and M. Rosenzweig, 'Defensive Stock Repurchases' (1986) 99 Harv L Rev 1377.

93 J. Coffee, The Uncertain Case for Takeover Reform: An Essay on Stockholders, Stateholders and Bust-ups' (1988) Wiscon L Rev 435, 459. 
the classic public good problem. ${ }^{94}$ The proper management of an inefficient target company is a public good to all the shareholders of the target. Grossman and Hart have pointed out that there are significant costs in ensuring that directors/managers act in the interests of the shareholders..$^{95}$ If one shareholder (acquirer) devotes resources to improving management, then all the shareholders benefit. ${ }^{96}$ The mandatory purchase provision exacerbates the externality problem by allowing the remaining shareholders of the target company to share equal gains from takeovers. This severe externality problem indicates that it cannot be assumed that a company which is not being run in the interests of shareholders will always be vulnerable to a takeover bid. An antidote of this externality problem is to exclude the remaining shareholders in the target from sharing equal gains resulting from takeovers ex post, hence an argument for abolishing the mandatory purchase provision at least at the low threshold of 30 per cent.

To understand how the imported takeover law adjusts to China's local conditions, we need to understand the ownership structure of the listed companies on the two stock exchanges. As discussed previously, the development of China's corporate law and the establishment of the stock market at the beginning of the 1990s were closely related to the reform of the state-owned enterprises. A survey in May 1999 reveals that among the 862 listed companies on the two stock exchanges, state shares exist in 541 listed companies, accounting for 62.76 per cent. ${ }^{97}$ Among the 541 listed companies, state shares account for 45 per cent of the total issued shares in these companies. ${ }^{98}$ In 473 listed companies, the state shareholder has either absolute or relative control ${ }^{99}$ of the company, occupying 87.43 per cent of the 541 listed companies. ${ }^{100}$ The state shares are mainly held by state asset administration bureaux, state investment companies or the parent companies of the state-owned listed companies. ${ }^{101}$ To be sure, the percentage of state ownership is much higher as state ownership may be held by legal persons of state-owned companies. ${ }^{102}$ In 70.79 per cent of the 541 listed companies, state shares range from 30 to 80 per

94 See Paul Samuelson, The Pure Theory of Public Expenditure' (1954) 36 Rev Econ Statistics 386.

95 S. Grossman and O. Hart, Takeover Bids, the Free-Rider Problem, and the Theory of the Corporation' (1980) 11(1) Bell J Econ 42 at 59.

96 See F. Easterbrook and D. Fischel, 'Corporate Control Transactions' (1982) 91 Yale $L J 698$ at $705-6$.

97 Zhang Zongxin and Sun Yewei, The Optimization of Shareholding Structure and the Improvement of Corporate Governance in Listed Companies' (2001) 1 Economic Review 36.

98 Ibid.

99 Absolute control means that the state controls more than 50 per cent of the issued shares and relative control means that the state controls more than 30 per cent of the issued shares.

100 Zhang and Sun, above n. 98.

101 lbid.

102 Ibid. 
TAKEOVERS IN CHINA: THE CASE AGAINST UNIFORMITY IN CORPORATE GOVERNANCE

cent. $^{103}$ Different from the shares held by individuals, which are traded at the two stock exchanges, state shares and legal person shares of state-owned enterprises are not traded. Another piece of statistics shows that traded shares owned by individual investors in most listed companies are only between 25 and 40 per cent. ${ }^{104}$

The structure of shareholding in most listed companies makes it impossible for an acquiring company to accumulate control through buying shares on any stock exchange. So far, there has been no successful acquisition of control of a listed company by purchasing shares on the stock market. To acquire a sufficient percentage of shares in a target listed company, instead, requires the purchase of part of the non-traded shares owned by the state or other companies. This makes the negotiated takeover the preferred method of takeovers in China. Under this method, an acquiring company negotiates with a majority or block shareholder and enters into a share transfer agreement with that shareholder in the target listed company.

Negotiated takeovers in China, however, have to overcome some procedural and legal hurdles. On the procedural side, acquiring state shares or legal person shares of state-owned enterprises requires approval by the relevant authority. Article 29 of the Provisional Measures on the Administration of State-owned Shares of Joint Stock Companies provides that the transfer of state-owned shares needs the approval of the State Asset Administration Commission and the provincial government. ${ }^{105}$ Transferring more than 30 per cent of the stateowned shares in a listed company requires the joint approval of the State Asset Administration Commission and the State Economic Restructuring Commission. ${ }^{106}$ The approval procedure is consistent with the goal of the government to maintain control of the large SOEs on the stock market.

In addition to overcoming this procedural hurdle, negotiated takeovers have to comply with the requirement of the mandatory purchase provision, which is central to the London City Code. The cost of following such a mandatory purchase provision is well recognized by regulators in China. ${ }^{107}$ The practice of dealing with negotiated takeovers and the adjustment of the English-style takeover law to the Chinese takeover market reflect the concern that strictly following the mandatory purchase provision is inefficient.

103 Ibid.

104 Zhang Rui, 'A Legal Analysis of Negotiated Takeovers of Listed Companies' (2003, July) Jilin University Journal (Social Sciences) 108 at 109.

105 These administrative rules were jointly issued by the State Asset Administration Bureau and the State Economic Restructuring Commission on 13 November 1994. The document can be found in the legal database available online at <http://www.chinainfobank.com >

106 Ibid.

107 Zhang Xin, 'Legislation and Regulation of Takeovers of Listed Companies' (2003, August) Securities Market Herald 12. 
The first negotiated takeover took place in 1994 under the early takeover regime. Hengtong Investment Ltd (Hengtong) was incorporated in Zuhai in $1981 .{ }^{108}$ Focusing on real estate development, Hengtong has also developed into areas of shipping, communications, textile and electronic products. To market its electricity meters in Shanghai, Hengtong planned to acquire a property development company in Shanghai. Search efforts revealed that Shanghai Lingguang Ltd (Lingguang), which produces glass and electronic components, is a suitable target. Lingguang issued 33.8 million shares in total. Among all the issued shares, Shanghai Construction Ltd held 55.26 per cent of the shares on behalf of the state while individual investors and legal person investors accounted for 32.55 per cent and 11.89 per cent of the shares respectively. Shortly before the transfer of control, the price of the shares of Lingguang was trading around 13 yuan per share on the secondary market. Hengtong's motivation in acquiring a controlling block of the shares of Lingguang was twofold: (1) mainly to rely on Shanghai Construction Ltd's connection with the property market in Shanghai, and (2) partly to take advantage of Lingguang's technology. The deal was encouraging news to Lingguang and Shanghai Construction Ltd based on the information available then as Lingguang was short of funds to carry out ambitious development projects. An agreement was reached among Hengtong, Shanghai Construction Ltd, and Lingguang to transfer 35.5 per cent of the shares held by Shanghai Construction Ltd to Hengtong at the price of 4.3 yuan on 28 April 1994. Transferring more than 30 per cent of the shares of a target, however, triggers the mandatory purchase provision. To avoid the high cost of mandatorily purchasing the remaining shares of Lingguang, Hengtong applied to the China Securities Regulatory Commission (CSRC) for an exemption from the mandatory purchase requirement. The CSRC granted its permission mainly on the ground that the transferred shares were the non-trading stateowned shares. ${ }^{109}$

The Hengtong case raises a number of questions. Could the CSRC approve the transfer price of 4.3 yuan when the individual shares traded on the secondary market were around 13 yuan? Is the significant discount of control shareholding able to ensure that the productive resources of the target would move towards a more efficient purchaser? Another question is the legal ground that the CSRC gave the exemption from the mandatory purchase obligation when the ITS contains no legal provisions, which confers the discretion on the CSRC. The lack of legal provisions of course does not constrain the CSRC when the rule of law is not deeply entrenched in China. Finally, 109 Ibid. 
should China follow the US approach by exempting transfer of control through agreement under the need of protection test ${ }^{110}$ if it is well recognized that the cost of following the English mandatory purchase provision is too high?

Later development of the takeover law partially addressed the issues arising from Hengtong. The Securities Law ${ }^{111}$ modifies the mandatory purchase provision and deliberately gives the CSRC the discretion to exempt acquirers from following the mandatory purchase requirement if they acquire shares through any stock exchange. ${ }^{112}$ The modified mandatory purchase provision now provides that if an investor holds 30 per cent of the issued shares of a listed company and continues to buy such shares through a stock exchange, the investor shall make a takeover offer to all the shareholders of the target listed company. ${ }^{113}$ The Securities Law seems to make a difference with respect to negotiated takeovers. Article 89 of the Securities Law stipulates:

In the case of takeover by agreement, the acquirer may execute the equity transfer by entering into an agreement with shareholders of the target company as prescribed in laws and administrative regulations.

When a listed company is taken over by agreement, the acquirer must, within three days after the agreement is reached, submit a written report on the takeover agreement to the State Council's securities regulatory authority and the stock exchange, and make an announcement.

The above Article seems to be based on the need of protection test in US securities regulation on the ground that the selling of shares by sophisticated investors does not need the protection of law. ${ }^{114}$ It is relatively clear that the Article does not expressly compel the acquirer to make an offer to all the shareholders in a negotiated takeover. Nor does the Article require the acquirer to obtain approval from the CSRC for such a negotiated takeover except for the compliance with the reporting and announcement requirement. The Article seems to recognize the high cost of the mandatory purchase provision and the need of a corporate control market to improve the inefficient stateowned listed companies. This Article, however, has not been used in that way. The CSRC's position is that, whatever the method of acquiring control, the mandatory purchase provision must be complied with unless it granted the acquirer an exemption. This position is consistent with the practice of negotiated takeovers in China. By the end

110 Hanson Trust v SCM 774 F 2d 27 (2d Cir, 1985).

111 This Law was promulgated on 29 December 1998 and became effective on 1 July 1999. An English translation appears at China Law \& Practice (Asia Law and Practice Publishing Ltd: Hong Kong, February 1999) 25.

112 Securities Law, Art. 81.

113 Ibid.

114 Kennecott Copper Corp. v Curtiss-Wright Corp. 584 F 2d 1195 (2d Cir, 1978); Hanson Trust, above n. 111. 
of 2000, all the 121 negotiated takeovers had followed the pattern of Hengtong in that an exemption was obtained from the CSRC. ${ }^{115}$

As discussed previously, most of China's state-owned enterprises on the stock market are not very efficient. A study has found that there is a negative correlation between firm performance and the percentage of state-owned shares. ${ }^{116}$ Empirical evidence in another study also suggests that takeovers in China are largely efficient compared with the status of many companies before the takeover although the market could be more efficient if ideological issues are properly dealt with. ${ }^{117}$

The inefficiency of the state-owned listed companies and the need of an active takeover market to facilitate the reallocation of productive resources require that China should modify the English-style takeover law in the Chinese takeover environment. This objective has led the CSRC to reconsider its position on negotiated takeovers. In 2002, the CSRC issued the Procedures on the Administration of the Takeover of Listed Companies (Takeover Procedures). ${ }^{118}$ While the Takeover Procedures reaffirm the position of the CSRC that, whatever the method of acquiring more than 30 per cent of the shares in a target listed company, the mandatory purchase requirement must be complied with unless exemption from the CSRC is obtained, ${ }^{119}$ the Takeover Procedures have provided numerous grounds upon which the CSRC is prepared to grant an exemption.

Among the exceptions, some are related to debt restructuring and insolvency reorganization. For instance, an exemption will be given if the transfer of shares is applied for on the basis of a court ruling and results in the percentage of shares held by the purchaser exceeding 30 per cent of the listed company's issued shares. ${ }^{120}$ An exemption will also be provided if a bank engaging in the normal business has acquired more than 30 per cent of the issued shares of a listed company but the bank has no intention of taking or has taken no action actually to control such a listed company and has made arrangements to transfer the excess shares to non-affiliated parties. ${ }^{121}$ The exemption on insolvency is provided to an acquirer which is taking over a listed company in financial distress in order to rescue it and has proposed a feasible restructuring plan. ${ }^{122}$

115 Li Bingan, 'A Discussion of the Exemption from the Mandatory Purchase Provision' (2003, November) 18(6) Legal Forum 50.

116 He Xiaogang, 'Management Buyouts: the Status Abroad, Research, and Development in China' (2003) 4 Reform 54.

117 Fei Yiwen and Cai Mingchao, 'An Analysis of the Takeover Effects of Listed Companies on the Shanghai Stock Exchange' (2003) 5 World Economies 64.

118 An English translation of the Takeover Procedures can be found in China Law \& Practice (Asia Law and Practice Publishing Ltd: Hong Kong, November 2002) 43.

119 Takeover Procedures, Arts. 13, 14 and 23.

120 Ibid., Art. 49(4).

121 Ibid., Art. 51(4).

122 Ibid., Art. 49(2). 
Other exceptions are based on the ground that no shareholder in a target listed company has received any takeover premium; for example, when an acquirer accumulated more than 30 per cent of the shares of a listed company resulting from the company's issuing new shares. ${ }^{123}$ Another exception is if the acquisition of more than 30 per cent of the issued shares of a listed company is caused by the reduction of the capital of the company. ${ }^{124}$

In the past, the CSRC frequently gave exemptions if governmental transfer of state-owned shares had caused the transferee to hold more than 30 per cent of the issued shares of a listed company. This exemption is still kept. ${ }^{125}$ Finally, the Takeover Procedures have added a catch-all provision, giving the CSRC the discretion to exempt the mandatory purchase provision if the CSRC considers it necessary to meet the needs of the development and changes of the securities market and the need to protect the legitimate rights and interests of investors. ${ }^{126}$ The transfer of control through administrative means as practised in the past has made the mandatory purchase provision largely irrelevant. If the catch-all provision is also liberally used, the mandatory purchase provision will also be made partly irrelevant.

The discussion of the adjustment of the English-style mandatory purchase provision clearly shows that application of the provision in China is path-dependent. The political goal of maintaining control of the state-owned listed companies has completely changed the rationale of using such a provision. The past socialist system of public ownership of the means of production created interested parties which controlled both the political and economic resources. These interested parties will try to protect their vested rights and interests. A very important way of continuing their control is to maintain the control of the large state-owned listed companies. The insistence of this political goal requires a different way of using the law of takeovers. I echo the view of Art and Gu that China's developing securities market can be properly understood only in the context of its underlying motivation, by carefully avoiding the mistake of assuming that adoption of western-style structures and laws implies movement toward western goals. ${ }^{127}$

If we take the ex ante efficiency view discussed previously, the adjustment of the imported takeover law is very positive in the sense of achieving the primary goal of improving the large number of inefficiently run state-owned listed companies. Another positive use of the English-style takeover law is the adoption of the position of nonfrustration on the part of the directors in a target listed company

127 Art and $\mathrm{Gu}$, above n. 44 at 139. 
when facing a takeover offer. ${ }^{128}$ Article 33 of the Takeover Procedures provides that the decisions made and measures taken by the directors, supervisors and senior management of the target company with respect to the takeover offer made by an acquirer may not prejudice the legitimate rights and interests of the company or its shareholders. More specifically, the said Article prohibits the adoption of measures of issuing new shares or convertible bonds, the repurchase of its own shares, the amendment of articles of association, and the signing of contracts, which could have a major effect on the company's assets, liabilities, rights, interests or business outcome except in the ordinary course of business, after an acquirer has announced its takeover intention.

In the United States, whether the board of directors of the shareholders should be given the ultimate power to decide whether the company should be sold to a bidder that offers to buy all the company's shares at a substantial premium above the current stock market price is very controversial. Easterbrook and Fischel argue that the management should remain completely passive in the face of a takeover bid. ${ }^{129}$ Their argument is based on the assumption that most takeovers are efficient in that they discipline bad managers in the target. When bad managers are facing a takeover bid which tends to remove them, it is unlikely that their action of defeating the takeover will be for the best interests of the company. ${ }^{130}$ Bebchuk argues that, once mechanisms to ensure undistorted shareholder choice are in place, boards should not be permitted to block offers beyond the period necessary for putting together alternatives for shareholder consideration. ${ }^{131}$ In contrast, Lipton argues against a regime of shareholders voting and no board veto. ${ }^{132}$ According to Lipton, there are significant costs to companies in being managed as if they were constantly for sale. ${ }^{133}$

The Delaware General Corporation Law (DGCL) takes a middle ground. The DGCL gives the board of directors a central role in corporate decision-making, ${ }^{134}$ but it also requires stockholder assent for many fundamental transactions. ${ }^{135}$ The DGCL is, however, silent on the most contentious question in the debate: in what circumstances, and to what extent, are directors empowered to prevent shareholders from accepting a tender offer? The Delaware courts also follow a

128 General Principle 7 of the London City Code, above n. 64.

129 See F. Easterbrook and D. Fischel, The Proper Role of a Target's Management in Responding to a Tender Offer' (1981) 94 Harv L Rev 116.

130 See A. Schwartz, The Fairness of Tender Offer Prices in Utilitarian Theory' (1988) 17 JL Stud 165.

131 L. Bebchuk, 'The Case Against Board Veto in Corporate Takeovers' (2002) $69 U$ Chi L Rev 973.

132 M. Lipton, 'Pills, Polls, and Professors Redux' (2002) 69 U Chi L Rev 1037.

133 Ibid. at 1078.

134 See, for example, 8 Del Code Ann \$ 141 (2001).

135 See, for example, ibid. § 251 (2001), § 271 (2001). 
middle ground. While in principle Delaware case law holds that the purpose of the company is to maximize the wealth of its stockholders, ${ }^{136}$ Delaware decisions also give directors substantial authority to deploy the powerful weapon of a poison pill ${ }^{137}$ and to block takeover offers that appear to be in the best interests of the current array of stockholders. ${ }^{138}$ The Delaware courts, however, have subjected defensive measures to a heightened form of judicial review under which directors must prove the reasonableness and good faith of their actions. ${ }^{139}$ The result is a regime in which directors are given substantial authority to forge corporate strategies while leaving room for stockholders to vote down management preferred directors and to use the election process to avail themselves of a tender offer. ${ }^{140}$

The adoption of the English-style mandatory purchase provision at the beginning of the 1990s has educated regulators in China relatively well on other parts of the London City Code. When the CSRC issued the Takeover Procedures in 2002, it again chose the English position of non-frustration over the Delaware type of takeover law on the proper role of the target board when the target is facing a takeover offer. The choice is largely satisfactory in the context of China. There are at least two reasons. Delaware law is very complicated. At this stage, regulators and judges in China are still not sophisticated in takeover law. To expect them to administer the Delaware type of takeover law when even the judges in other parts of the United States are not able to do it well is likely to be counterproductive. Second, directors in the United States are subject to greater constraints by very strict fiduciary duties, derivative suits and various market mechanisms which are not available in China. ${ }^{141}$

While the adoption of the English-style takeover law and the adjustment of the law in China are in the right direction, negotiated takeover transactions in China have a serious defect. As discussed previously, only shares held by individuals in listed companies are traded on the two stock exchanges. State shares and legal person shares of state-owned enterprises are not traded on the stock exchanges. This raises the issue of pricing the control block of stateowned shares. In the Hengtong case, the control block was priced at 4.3 yuan per share when the shares traded at the stock exchange were around 13 yuan per share. ${ }^{142}$ The Opinions Concerning the Exercise of

136 See, for example, Cede \& Co. v Technicolor Inc 634 A 2d 345, 360 (Del 1993).

137 See, for example, Unitrin Inc v American General Corp. 651 A 2d 1361, 1390 (Del 1995).

138 Paramount Communications Inc v Time Inc 571 A 2d 1140, 1150.

139 Moran v Household International Inc 500 A 2d 1346, 1356 (Del 1985).

140 See W. Allen et al., The Great Takeover Debate: A Meditation on Bridging the Conceptual Divide' (2002) 69 U Chi L Rev 1067.

141 For a regulator's view, see Zhang Xin, above n. 108 at 15-17.

142 Hengtong, above n. 109. 
State-owned Shares in Joint Stock Companies ${ }^{143}$ dictate that the lowest transfer price of state-owned shares is the net asset value per share. ${ }^{144}$ In Hengtong and all the other cases before 2004 when the control block of state-owned shares was transferred, the price of the shares of the block was several times lower than the price of the shares traded on the stock market. In a few cases, even the requirement of the lowest transfer price of net asset value per share is not followed. ${ }^{145}$ The practice of negotiated takeovers in China also indicates why the mandatory purchase provision, which is central to the London City Code, is not followed in China. The mandatory purchase provision is based on the premise that the acquirer has to extend the same premium to all other shareholders in the target if it buys shares at a price higher than the market price from the majority, block or some shareholders, who are more likely to get the benefits because of their position. This ensures the equality of treatment of all shareholders in the target. In China, when the control block is priced at a much lower price than the market price of other shares traded on the stock market, the mandatory purchase provision loses its rationale. This again leads to the conclusion that the political goal of maintaining the control of state-owned listed companies has made the imported law considerably irrelevant. While not following the mandatory purchase provision can be justified on efficiency grounds, cheap transfer of the control block in China left minority shareholders with no adequate protection.

In the United States and United Kingdom, the concern of takeover law is to ensure the minority shareholders a premium over the market price if the acquirer gains control by offering the outgoing shareholder(s) in the target a price higher than the market price. Because of the benefits of control, the price of the control block is normally higher than the price of the shares of a target on the secondary market. The higher price of the control block is a basic market mechanism to protect the minority shareholders in that only those who are able to manage the target better are willing to obtain the control given the constraints. There might be mistakes in prediction or judgement on the part of the acquirer and the effect of takeover may be disastrous. The market in the long run will correct the mistake. The cheap transfer of control in China, however, is not able to ensure that acquirers are necessarily better than the existing management in targets. Furthermore, the discount of the share price of the control block

143 The Opinions were jointly issued by the State Asset Administration Commission and the State Economic Restructuring Commission on 29 August 1997 and are available online at <http://www.chinainfobank.com > .

144 Ibid., Art. 17.

145 Wang Huacheng and Tong Yan, Management Buyouts in China: The Case of Media' (2002) 10 Economic Theory and Management 66; An Chunmei and Dou Zhanguo, 'An Analysis of Benefits and Risks of Management Buyouts in Listed Companies' (2002) 7 Finance and Accounting Research 52. 
creates serious risks of exploitation of minority shareholders. Recently, the State Asset Administration Bureau and the Ministry of Finance jointly issued the Provisional Measures on the Administration of the Transfer of State-owned Shares in January 2004 (Provisional Measures). ${ }^{146}$ The Provisional Measures now permit but do not compel the use of auctions or biddings in takeovers in addition to negotiated takeovers. Similar to other administrative rules, these Provisional Measures are more interested in ensuring that the stateowned assets are not depleted in low price transfer of control to private-sector enterprises.

While auctions and biddings in takeovers will alleviate the problem of cheap transfer of control in listed companies in China, the move towards an efficient takeover market requires a radical reform of large-scale exit of state-owned enterprises in many sectors of the economy. State-owned enterprises are unlikely to be efficient. As Trebilcock has persuasively argued, there are not adequate means to motivate the agents in state-owned enterprises and there are not adequate means to discipline such agents in state-owned companies compared with the means available to private-sector firms. ${ }^{147}$ To realize the goal of achieving efficiency through corporate law in general and takeover law in particular, the Chinese government must abandon the concept of controlling the state-owned listed companies for the purpose of political control. Only then can the law of takeover fully realize its efficiency goal.

The discussion in Part ii shows that the use of the transplanted English-style takeover law has been significantly affected by China's social and political factors. The adaptation of that law in China is not only path-dependent but also very local in nature and with legislative and administrative innovations. This again raises serious doubt whether a single corporate governance model fits all countries.

\section{Conclusion}

Corporate governance has attracted enormous attention both in the area of law and in the area of financial economics. In comparative corporate governance studies, many people have devoted their energy to finding a best corporate governance model. I argue that a functional analysis does not support the view that there is a single best model in the world. I further use the transplantation of an English-style takeover law into China to explain that the importation of a foreign law is not always based on careful analysis whether the imported foreign law is the best in the world. Furthermore, I discuss the subsequent adjustment of the transplanted English takeover law to the takeover

146 These Provisional Measures are available online at < http://www.chinainfobank. com >.

$147 \mathrm{M}$. Trebilcock and E. Iacobucci, Commentary: 'Public Values in an Era of Privatization: Privatization and Accountability' (2003) 116 Harv L Rev 1422. 
market in China to show that the transplantation of foreign law is subject to local political and economic conditions. If there is no best corporate governance model and the transplantation of foreign law into other countries with different social and political background does not achieve similar objectives, the search for a best corporate governance model is misguided. 